\title{
ТЕОРЕТИЧНА ФІЛОСОФІЯ І. КАНТА: ДО ПИТАННЯ ПРО ДЕЯКІ СТЕРЕОТИПИ ЇЇ ЕКСПЛІКАЦІї
}

\begin{abstract}
О.П. Панафідіна
Трансцендентальну філософію Іммануїла Канта прийнято співвідносити 3 подальшими ученнями німецьких філософів раціоналістичного напряму - І.Г. Фіхте, Ф.В.Й. Шеллінга і Г.Ф.В. Гегеля. Причому дана інтенція характерна як для вітчизняної філософської традиції, так і для західної. Перша і сьогодні, як правило, користуеться запропонованим $Ф$. Енгельсом поняттям «класична німецька філософія», а друга іменуе школу, до якої належали вказані мислителі, «німецьким ідеалізмом». Як відомо, поняття філософської школи позначае сукупність мислителів, котрі ідентифікують себе як послідовники вчення одного зі своїх попередників. Приймаючи дане визначення i, більш того, погоджуючись 3 тим, що Фіхте, Шеллінг і Гегель, дійсно, багато в чому відштовхувалися від деяких кантівських ідей, ми все ж таки стверджуємо неправомірність тези, відповідно до якої І. Кант проголошується засновником класичної німецької філософії або ж німецького ідеалізму XIX століття.

Марксистська традиція, розглядаючи класичну німецьку філософію в якості одного зі свої «живильних теоретичних джерел» (Н.В. Мотрошилова), шукае у філософії І. Канта, перш за все, підстави діалектичного методу, найбільш повне обгрунтування якого належить Г. Гегелю. Матеріалістична інтерпретація даного методу, у свою чергу, складае ядро філософських ідей К. Маркса і Ф. Енгельса. Тому «без Фіхте і Гегеля неможливо зрозуміти Канта», оскільки Фіхте «ясно і недвозначно висловлюе те, що implicite було дане в трансцендентальній
\end{abstract}

Актуальні проблеми духовності:

зб. наук. праць / Ред.: Я.В. Шрамко

Вип. 11. - Кривий Ріг, 2010, 37-57

ISSN 2076-7382 
філософії Канта» [2, Гл. 1]. L.С. Нарський говорить про «започаткований Кантом могутній теоретичний рух», «головним завоюванням» якого є діалектика $[15$, с. $6,9-10]$. Т.Б. Длугач, достатньо високо оцінюючи учення Канта і порівнюючи його «вплив на всю подальшу европейську філософію» 3 тим впливом, який справив У. Шекспір «на розвиток світової літератури або ж Бетховен, - на розвиток музики», указуе на те, що «Критика чистого розуму» «була першим кроком у новому напрямі, що увійшов в історію під назвою німецька класична філософія» $[7$, с.3].

Н.В. Мотрошилова також наполягає на тому, що «біля витоків діалектичної думки. . . лежали розмірковування саме Канта» як «родоначальника німецької класичної філософії» - «пілісного духовного утворення» (або, принаймні, «відносно цілісного утворення») [14, с.304308].

Амбівалентну позицію в цьому питанні займае B.I.Шинкарук, який, з одного боку, стверджує, що «філософія Канта поклала початок німецькому класичному ідеалізму, визначила його початковий принцип, намітила коло тієї філософської проблематики, що його цікавила». Більш того, теза про те, що Кант є «родоначальником німецької класичної філософії», винесена в назву його монографічного дослідження. Але, з іншого боку, В.І. Шинкарук мусив визнати, що «при всьому тому „духовним батьком“ німецького класичного ідеалізму був, звичайно, не Кант» 22 , с. 186]. Сам же I. Кант в його «трансцендентальній логіці» «великий постановкою питання, а не його вирішенням», оскільки «його антиномії і не були ще дійсними діалектичними суперечностями». «Тому точку зору, що Кант $є$ „засновником діалектичного способу мислення", навряд чи можна вважати такою, що відповідае істині» [22, с. 103, 181-182].

Аналогічна позиція характерна і для В.Ф. Асмуса, який в передмові до роботи «Іммануїл Кант» стверджує, шо «саме з Канта започатковується течія діалектичного ідеалізму, представлена великими іменами не тільки Канта, але й Фіхте, Шеллінга і Гегеля» $[1$, с. 1]. Проте в одній із глав даної праці він приходить до кардинально протилежного висновку: «мислитель, який відродив діалектичну традицію, - у своєму мисленні, в самих підвалинах своеї логіки, був вкрай антидіалектичним». Більш того, з точки зору В.Ф. Асмуса, «недоліки кантівської діалектики проявляються не в... деталях», а «вражають ядро всієї системи, незмінно проявляючись як у викладі $\dddot{1}$, так $і$ кінцевих висновках» $[1$, с. 276$]$.

Що стосується інтерпретації кантівського вчення, превалюючої в 
західній філософській традиції, про яку ми можемо судити хоч би із загальнодоступної англомовної літератури енциклопедичного характеpy (див., напр., [24]), то воно зараховується до т. зв. німецького ідеалізму виходячи дешо з іншої підстави, ніж у вітчизняній філософській традиції. Акцентується увага не на діалектичному методі, а на ідеї трансценденталізму, тобтт пріоритету розуму над природою, активності свідомості в ході пізнання дійсності. Фіхте, Шеллінг і Гегель, як безпосередні послідовники Канта, розвинули ті ідеі, що закладені в його трансцендентальному ідеалізмі. Отже, школа німецького ідеалізму представлена критичним ідеалізмом Канта, суб'єктивним ідеалізмом Фіхте, об'єктивним ідеалізмом Шеллінга і абсолютним ідеалізмом Гегеля (або ж, в інтерпретації В. Віндельбанда, «етичним», «фізичним» і «логічним» ідеалізмом відповідно). У розвитку цієї філософської школи простежується тенденція поступової елімінації моменту реальності і субстанціальності зовнішнього світу, незалежного від якоїсь ідеальної суті. У Портленді (США) існуе філософське Товариство німецького ідеалізму (The Society for German Idealism), яке безпосередньо займається вивченням творчої спадщини саме цих чотирьох мислителів кінця XVIII - першої половини XIX століття (назва красномовно говорить саме за себе).

Ні вітчизняна (марксистська), ні вказана західна інтерпретації теоретичної філософії Канта не $\boldsymbol{\epsilon}, 3$ нашої точки зору, прийнятними. Більше того, в роботах самого Канта можна знайти безліч аргументів, що спростовують правомірність наступних тверджень: (1) нібито він є засновником діалектики як теорї розвитку або ж (2) безпосередньо належить до ідеалістичного напряму у філософії як такого. Обгрунтуванню цих двох тез і присвячена дана стаття.

Найбільш розробленим ми знаходимо діалектичне вчення у Г. Гегеля. Згідно Гегелю діалектика $\boldsymbol{e}$ «іманентним переходом одного визначення в інше, в якому виявляється, що ці визначення розсудку однобічні й обмежені, тобто містять заперечення самих себе. . . Діалектика $\varepsilon$, отже, рушійною силою будь-якого наукового розгортання думки і виступає єдиним принципом, що вносить до змісту науки іманентний зв'язок і необхідність, в якому взагалі полягає справжне, а не зовнішне піднесення над конечним» [4, с. 206]. Гегель достатньо високо оцінюе кантівську ідею антиномічності людського розуму, проте розглядає їі як «негативний результат», що не дозволяє пізнати «дійсне і позитивне значення антиномій». Останне ж полягае «в тому, що все дійсне містить в собі протилежні визначення і що, відповідно, пізнання i, точніше, осягнення предмету в поняттях якраз і означае пізнання його 
в якості конкретної єдності протилежних визначень» [4, с. 167]. Антиномії чистого розуму у Канта, дійсно, представлені у вигляді тези й антитези, проте спосіб їх вирішення не співпадає з тим, що запропонував Гегель. Як справедливо зауважуе В.Ф. Асмус, Кант не дав «діалектичного вирішення проблеми суперечності», навпаки, «діалектичну по суті суперечність Кант намагається вирішити засобами формальної логіки» [1, с. 291]. Якщо Гегель виходив з істинності й тези, й антитези, чим заперечував закон суперечності як один із законів традиційної логіки, то Кант прагнув обгрунтувати позірність суперечності між тезою i антитезою. Перші дві антиномії, які Кант відносив до класу математичних, вирішуються шляхом проголошення хибності обох тверджень на тій підставі, що причиною позірної суперечності $є$ хибність їхнього вихідного поняття - поняття про світ, що поєднує в собі два значення: світ явищ і світ речей самих по собі. Що стосується двох інших антиномій - динамічних, то їхні тези й антитези можуть бути одночасно істинними, але висловлюються про один і той же предмет, що перебуває в одному місці, у різних відношеннях. Відповідно, вони абсолютно не суперечать одне одному.

Канту в принципі не властива ідея синтезу протилежностей, котрий би демонстрував розвиток наукового знання і тим самим наближав розум, що пізнає, до істини. Однак саме ця ідея складає ядро гегелівської діалектики. Натомість І.С.Нарський відзначає, що «вирішення антиномій [у Канта]. . далеке від реального синтезу і. . взагалі не $е$ синтезом» $[15$, с. 99-100]. В.Ф. Асмус, у свою чергу, говорить про «величезні недоліки і пробіли» у «кантівському вченні про діалектичні антиномії. «Якщо Кант у своєму вченні про антиномії знову з силою висунув діалектичну проблему суперечності і завдяки цьому став піонером усієї новітньої діалектики, то, навпаки, спосіб викладення і доведення антиномій, а ще більше спосіб їхнього вирішення і пояснення у жодному разі не можуть бути визнані задовільними і такими, що відповідають природі й нормам діалектичного мислення» $[1$, с. $275-$ 276]. I далі, підсумовуючи аналіз «недоліків» діалектичної концепції Канта, В.Ф. Асмус висуває наступне положення: «Вчення Канта про антиномії вражає невідповідністю між геніальним діалектичним задумом і занадто вузьким, чисто формальним його вирішенням» $[1$, с. 289]. Отже, виходить, що І. Кант $\boldsymbol{e}$ родоначальником діалектики, оскільки розробив вчення про антиномії чистого розуму, що виникають 3 космологічних ідей, але в той же час він пропонував такі способи вирішення цих антиномій, які виходять за межі власне діалектики. Щоб подолати подібну суперечність, з нашої точки зору, необхідно окреслене коло 
ідей розглядати в контексті загальної кантівської програми «критики чистого розуму».

Трансцендентальна антитетика як вчення I. Канта про антиномії чистого розуму виходить 3 наявності двох тверджень, «з яких жодному не можна надати переваги перед іншим», якщо спиратися виключно на дані, отримані в ході спекулятивної діяльності розуму, що робить об'єктом пізнання недоступну для досвіду ідею світу в цілому. Причому ця хибна передумова покладена в основу як тези, так і антитези. На цій підставі Кант стверджуе, що «останнім засобом вирішення суперечки повинен зрештою служити досвід» $[8$, с. 257, 259]. Варто зауважити, що кантівська антитетика протистоїть тетиці - «сумі всіх догматичних вчень». Оскільки сутність філософського догматизму полягає у прагненні захищати певну точку зору, неважливо тезу чи антитезу, то він виходить з принципу монологізму. Кант же, протиставляючи свій критицизм будь-яким формам догматизму, розробляе антитетику чистого розуму, котра «займається аж ніяк не однобічними твердженнями, а розглядае загальні знання розуму тільки 3 точки зору суперечності їх між собою і причин цієї суперечності» [8, с. 257].

Н.В. Мотрошилова справедливо вказуе на ту обставину, що в даному уривку 3 «Критики чистого розуму» у самого Канта йдеться не про суперечність між протилежними догматичними твердженнями, а про суперечку (в оригиналі: Widerstreit) між ними (див.: [14, с. 420]). У такому випадку відмінність кантівської антитетики від тетики полягає у тому, що перша за своєю природою $є$ діалогічною. Тому «спроби об'єднання. . . тверджень. . . [трансцендентального розуму] одне з одним» Кант зводить передусім до «спроб вільного й безперешкодного змагання їх між собою» $[8$, с. 259$]$.

Виходячи 3 зазначеного, можна провести певні паралелі між скептичним методом Канта і діалектичним методом Сократа (відмінного від методу софістів), а також ідеєю інтелектуальної комунікації K.P.Поппера. Адже згідно з Кантом «скептичний метод має своєю метою достовірність, намагаючись знайти у суперечці, що ведеться 3 обох боків чесно й з розумом, те, що викликає непорозуміння», оскільки «розум не легко помічае свої помилки в абстрактній спекуляції» [8, с. 259]. Саму діалектику він іменуе «пустим діалектичним мистецтвом», «хиб́ною видимістю», протиставляючи її науці [9, с. 595]. Та ж діалектика, яка набула формальної досконалості у філософській системі Гегеля, напевне, є не продовженням і завершенням учення Канта про антиномії чистого розуму, а прямою його протилежністю, чимось схожою на докантівський догматизм (якщо під догматизмом розуміти 
антикритицизм). Адже Кант критикував всю попередню догматичну метафізику саме за те, що вона претендувала на пізнання трансцендентного, тобто того, що не має відношення до будь-якого можливого досвіду. T.I. Ойзерман в одній зі своїх останніх робіт, присвячених дослідженню філософії І. Канта, вказуе на дуже важливий її аспект, а саме: зв'язок з теоретичним природознавством. Зокрема він відзначає, що «завдяки вченню Канта про апріорне пізнання метафізика, яка спочатку претендувала на наддосвідне знання, стає апріорним філософським пізнанням у межах можливого досвіду», «історично першою теорією наукового пізнання», «філософським обгрунтуванням теоретичного природознавства, що зароджувалося за часів Канта» [16, c. 25,28$]$.

У той час як Кант обгрунтовував марність будь-яких спроб пізнати трансцендентне, тим самим обмежуючи претензії теоретичного розуму, один з представників німецького ідеалізму - Ф.В.Й.Шеллінг в роботі «Філософські листи про догматизм і критицизм» (1795), навпаки, говорить про «надзвичайну привабливість догматизму». Більше того, він стверджує, що «навіть довершена система критицизму не може теоретично спростувати догматизм. Правда, теоретична філософія нищить його, але він знов піднімається з ще більшою силою» [21, с. 49]. Шеллінг в цих «листах» опонуе уявному адресатові, який нібито виходить 3 достатньо поширених «хибних тлумачень» «Критики», і заявляє: «Недосконалість, слабкість [розуму] - хіба це не випадкові обмеження, що допускають нескінченне розширення? . . Х Хіба разом 3 вірою в згадану обмеженість ви не поклали на себе і обов'язок використовувати всі засоби для їі усунення?» $[21$, с. 46]. Наведені висловлювання Шеллінга, як видно, свідчать про те, що його вчення протистоїть кантівській ідеї «критики чистого розуму». Він прямо говорить: «Я, безумовно, надаю перевагу старому чесному вольфіанцю; той, хто не вірив його доказам, вважався просто не здібним до філософствування» $[21$, c. 46$]$.

Отже, ми маємо дві принципово відмінні одна від одної позиції стосовно вирішення питання росту наукового знання: (1) гегелівська, заснована на ідеях Фіхте й Шеллінга, і (2) власне кантівська. Для Гегеля єдиним шляхом наближення до істини е шлях діалектичної тріади, а для Канта - поєднання апріорного пізнання з чуттевими спогляданнями. Тому, слідуючи гегелівському шляху, розум опиняється у сфері чистої спекуляції, хоча й володіе могутнім засобом теоретичного подолання будь-якої суперечності. Кантівський шлях, навпаки, застерігає від подібних спекуляцій і представляє собою своєрідний синтез емпіри- 
зму і рапіоналізму як гносеологічних підходів, що протиборствували в попередній період. Згідно з Кантом будь-яке пізнання починається 3 досвіду, але не обмежується ним (див: $[8$, с. 49]). 3 першого погляду це-суперечливе положення, проте насправді не е таким, що стае достатньо очевидним, якщо прийняти до уваги два чинники, принципово важливих в даному контексті. По-перше, йдеться про відмову Канта від традиційного онтологічного принципу тотожності мислення i буття, обгрунтованого ще Парменідом наприкінці VI - на початку V століття до н. е., і заміну його принципом їхньої протилежності, а подруге, про ідею «коперніканського перевороту» в гносеології.

Відповідно до принципу протилежності мислення і буття Кант вводить поняття трансцендентального суб'єкта i ding an sich (речі самої по собі). Якщо в попередній метафізиці і далі, наприклад, у Гегеля мислення є субстанціальною основою чуттевого світу, то у Кантаце здібність людини, що дозволяе отримувати знання про об'єктивну реальність, котра перебуває поза її свідомістю. Тому тільки у відношенні до предметів чуттєвого споглядання мислення може претендувати на онтологічний статус. 3 іншого боку, чуттеве пізнання не може забезпечити отримання всезагального і необхідного знання, яким, по суті, $є$ наукове знання. У зв'язку з цим Кант виділяє апостеріорне (емпіричне) i апріорне (чисте, позадосвідне) знання. На наш погляд, можна говорити і про третій вид знання, який відповідае загальному задуму кантівського трансценденталізму. Його умовно можна було б назвати науково-теоретичним. Йдеться про такий вид знання, яке $е$ апріорним, у сенсі додосвідного, гіпотетичного, але в той же час таке, що потенційно перевіряеться в можливому досвіді. Можна погодитися 3 T.I. Ойзерманом, котрий стверджував, що «теоретичне дослідження завжди виходить за межі наявного досвіду і разом з тим завжди залишаеться у межах можливого досвіду» [16, с.28]. Саме 3 цих позицій, мабуть, виходив К.Р. Поппер, розробляючи фальсифікаційний критерій демаркації наукового знання. Якщо ж обмежитися дихотомією апріорне/апостеріорне, то неврахованою залишається центральна кантівська ідея «критики чистого розуму», адже апріорне може інтерпретуватися виключно як чисте, незалежне від досвіду, а тому спекулятивне, ненаукове.

Принцип протилежності мислення і буття залишається незатребуваним у представників школи німецького ідеалізму, які, проте, позиціонують себе як «послідовники» трансцендентальної філософії І. Канта. Так, наприклад, Шеллінг вступ до роботи «Система трансцендентального ідеалізму» починає наступною фразою: «Будь-яке знання засно- 
ване на збігові об'єктивного і суб'єктивного» [20, с. 232]. (Ця робота, в основу якої автор поклав свій лекційний курс, була опублікована в 1800 році і відразу ж викликала жваві відгуки. Якщо пригадати реакцію, точніше кажучи практично її відсутність, німецької громадськості на першу публікацію «Критики чистого розуму» Канта, то подібна пожвавленість у зв'язку з виходом вказаної роботи Шеллінга, на наш погляд, свідчить не про що інше, як про співзвучність його ідей загальній інтенції епохи.) Згідно з Шеллінгом «у кожному знанні необхідним є збіг» об'єктивного («природи») і суб'єктивного («Я» або «інтелігенції), хоча буденна свідомість протиставляє їх. В іншій своїй роботі він пропонуе «зняти» «протиборство між суб'єктом і об'єктом», указуючи на два можливі шляхи: «або суб'єкт повинен розчинитися в об'єкті, або об'єкт - в суб'єктові [21, с. 51]. Інакше кажучи, Шеллінг виходить 3 принципу тотожності мислення і буття (що говорити про Гегеля, у якого Абсолютна Ідея є суб'єктом-субстанцією, яка пізнає себе в ході свого ж діалектичного розгортання!).

У зв'язку зі сказаним слід звернути увагу ще на одну особливість кантівського трансцендентального ідеалізму, який по суті не $е$ філософською системою, подібною до систем Платона або ж т. зв. «німецьких класиків». У Канта відсутній той системоутворюючий принцип, 3 котрого можна було б вивести його головні ідеї, яким у Платона, наприклад, виступають ідеї (як джерело різноманіття світу чуттєвих речей, як джерело знання, на відміну від гадки, тощо). Це відзначав свого часу В. Віндельбанд, указуючи на те, що вже К.Л. Рейнгольд був упевнений в існуванні такого центрального принципу, якому сам Кант просто не надав наукового формулювання. Тому Рейнгольд проголошуе завданням своєї елементарної філософії затвердити цей принцип і показати, як 3 нього 3 необхідністю витікають всі вчення критичної філософії [3, с. 208-209].

Проте йому це виявилося не під силу. Саме Фіхте «виконав вимогу Рейнгольда методично вивести всі їі [кантівської філософіiі] положення 3 одного принципу» $[3$, с. 221]. I таким основоположним філософським принципом стає у нього Я як чиста самосвідомість, самодіяльне і самодостатне мисляче Я, відмінне від емпіричного я. Відповідно до закону тотожкності він формулюе наступним чином перше з трьох основоположень свого науковчення: «Я покладає Я». Послідовник Фіхте Шеллінг у передмові до «Системи трансцендентального ідеалізму», формулюючи мету цієї праці, наводить тезу, згідно якій також проголошується необхідність «дати ідеалізм у всій його повноті», тобто «розширити трансцендентальний ідеалізм до тих меж, які дозволять йому стати 
... системою всього знання» [20, с. 228]. I далі у вступі до названої роботи він пише, що «для трансцендентальної філософії суб'єктивне $\boldsymbol{\epsilon}$ первинна єдина підстава всякої реальності, єдиний принцип пояснення всього іншого». Нарешті Гегель ототожнюе людську самосвідомість зі світовим духом на певному етапі його розвитку, а останній одночасно виступає у нього суб́станцією, що активно діє («ідея спочатку є лише єдина, загальна субстанція, але в своїй розвиненій, справжній дійсності вона е суб'єктом..., духом» [4, с. 400]). «Таким чином, Гегель виводить найрадикальніший висновок $з$ постулату тотожності мислення і буття, що визнавав організацію людського розуму, яка складала для Канта первинний предмет філософського пізнання, організацією світового розуму. Це - найбільш крайній висновок із руйнування поняття речі в собі, руйнування, яке вдалося здійснити Фіхте» [3, с.341].

Що стосуеться «коперніканського перевороту» в гносеології, то цю ідею неправомірно трактувати як певний засіб перетворення філософського учення Канта на деякий різновид філософії суб'єкта. I справа зовсім не в непослідовності або ж суперечності його вихідних положень, так званому філософському дуалізмі. Кант пропонуе погоджувати об'єктивно існуючі предмети 3 нашим пізнанням, що узгоджуеться з можливістю отримання апріорного синтетичного знання про ці предмети. Отже, ідея «коперніканського перевороту» стосуеться всього лише зміни співвідношення між знанням і предметом, суб'єктом і об'єктом пізнання, активності пізнаючого суб'єкта, проте зовсім не свідчить про елімінацію об'єктивного світу або ж про втрату його онтологічної самостійності. (Як відмічае Н.В. Мотрошилова, «Кант прагне ствердити, пояснити, відстояти творчо активний, самодіяльний характер людського пізнання» [14, с. 352].) Трансцендентальний суб'єкт, маючи такі пізнавальні здібності, як чуттевість, розсудок і розум, пізнае об'єктивну реальність, виходячи зі своїх пізнавальних можливостей. Тільки у цьому сенсі можна говорити про умовне розрізнення явища і речі самої по собі. Предмет, який виступає об'єктом пізнання, перетворюеться для пізнаючого суб'єкта на явище, але він же, не будучи об'єктом пізнання, залишається річчю самою по собі, тобто такою, що реально існуе в об'єктивному світі. Кантівське розуміння «речі самої по собі», як нам здається, можна в цілому співвіднести 3 класичним в рамках марксистської філософії визначенням поняття матерії, що належить В.Леніну. Відомо, що в «Матеріалізмі та емпіріокритицизмі» він дае т. зв. гносеологічне визначення матерії, підкреслюючи її дві характерні ознаки: (1) вона існуе незалежно від свідомості людини, але в той же час (2) впливає на органи чуттів і відображуеться 
в свідомості. Відтак, якщо слідувати термінології Канта, то матерія це «річ сама по собі», яка в ході процесу пізнання перетворюеться на «явище».

В світлі сказаного проблематичним виявляеться загальноприйняте в гегельянсько-марксистській традиції положення про нібито гносеологічний агностицизм Канта. Про принцип «трансцендентального незнання» як базовий принцип кантівської філософії писав і один із засновників ірраціоналістичної філософії Ф.Г.Якобі. Подібна інтерпретація вчення І.Канта базуеться, перш за все, на неприйнятті принципу протилежності мислення і буття, що становить ядро критичного трансценденталізму. У попередньому викладі, як нам представляється, достатньо сказано, щоб усунути подібні звинувачення на адресу Канта. Обмеження пізнавальних можливостей трансцендентального суб'єкта сферою можливого досвіду не має логічним наслідком заперечення можливості отримати достовірне знання про об'єктивно існуючий світ. Тому програма «критики чистого розуму» застерігае від неправомірних спекуляцій схоластичного толку і в той же час орієнтує на принципи науковості.

У вітчизняній кантознавчій філософської традиціі, як правило, використовують не зовсім вдалий переклад поняття Ding an sich як «речі в собі», тобто речі, принципово непізнаваної, на відміну від «речі для нас». Цікаво, що В. Ленін в роботі «Матеріалізм та емпіріокритицизм» говорить про два можливі переклади кантівського виразу «аn sich»: (1) «саме по собі» $\mathrm{i}(2)$ « собі» $[13$, с. 118]. А.В. Гулига указує на те, що «іноді ці два прочитання протиставляють один одному у зв'язку з тим, що у Канта разом з виразом Ding an sich зустрічається і Ding an sich selbst». Проте він посилається на Р. Праусса, який спеціально досліджував це питання і прийшов до висновку, що обидва вирази означають одне і те ж-Ding an sich betrachtet, тобто річ, що розглядаеться сама по собі $[5$, с. 370$]$.

Це уточнення представляється нам досить важливим для адекватної інтерпретації учення Канта, оскільки дає підставу характеризувати його дуалістичну позицію не в категоріях «непослідовності» або «еклектицизму», а як самодостатне учення, що претендує на певний ступінь філософської оригінальності, не вписується в загальноприйняті дихотомії «матеріальне/ідеальне» або «емпіричне/раціоналістичне». 3 погляду Канта, подібні опозиції орієнтують на «боротьбу, де кожного разу перемагає та сторона, якій дозволено почати напад, а терпить поразку, зрозуміло, та сторона, яка вимушена тільки оборонятися» $[8$, c. 258]. Інакше оцінка критичного трансценденталізму Канта нагаду- 
ватиме його характеристику, дану Леніним, виходячи з ідеї наявності «партій у філософії, що борються» (тобто матеріалізму й ідеалізму) і співвідношення т. зв. «третьої лінії у філософії» зі «скудоумною безпартійністю» $[13$, с. 380$]$. Зокрема він говорив: «Основною рисою філософії Канта $\boldsymbol{e}$ примирення матеріалізму з ідеалізмом, компроміс між тим і іншим, поєднання в одній системі різнорідних, протилежних фiлософських напрямів. Коли Кант допускае, що нашим уявленням відповідае щось поза нами, деяка річ в собі, - то тут Кант матеріаліст. Коли він оголошуе цю річ в собі непізнаваною, трансцендентною, потойбічною, - Кант виступає як ідеаліст. Визнаючи єдиним джерелом наших знань досвід, відчуття, Кант спрямовуе свою філософію по лінії сенсуалізму, а через сенсуалізм, за відомих умов, і матеріалізму. Визнаючи апріорність простору, часу, причинності і т. д., Кант направляє свою філософію у бік ідеалізму» [13, с. 206].

3 приводу інтерпретації учення Канта як ідеалістичного слід сказати окремо. Як відомо, у другому виданні «Критики чистого розуму» 1787 року автор даного твору додав розділ з доволі примітною назвою «Спростування ідеалізму», де він абсолютно заперечуе свою причетність як до проблематичного ідеалізму Р. Декарта, так і до догматичного ідеалізму Дж. Берклі. Кант вводить таке поняття, як «матеріальний ідеалізм», що позначае «теорію, котра проголошуе існування предметів в просторі поза нами або тільки сумнівним і недоказовим, або помилковим і неможливим» $[8$, с. 176]. 3 такого визначення слідуе, що поняття «матеріальний ідеалізм» в розумінні Канта охоплюе будьякий ідеалізм в онтологічному сенсі, протилежний матеріалізму, і що припускае визнання деякої ідеальної сутності субстанціальною основою світу чуттєвих речей. Там же він формулюе теорему, яку доводить в подальшому викладі: «Проста, але емпірично визначена свідомість мого власного існування служить доказом існування предметів в просторі поза мною» $[8$, с. 177]. Той факт, що подібний розділ був написаний Кантом до другого видання, ймовірно, свідчить про те, що автор намагався роз'яснити свою позицію в даному питанні, інтерпретація якої після виходу першого видання його головної гносеологічної праці в 1781 році була для самого Канта зовсім неприйнятна. До того ж можна відзначити той факт, що і після виходу другого видання «Критики чистого розуму» Кант продовжував розмірковувати над питаннями спростування ідеалізму. Про це свідчать, зокрема, деякі опубліковані чорнові матеріали, що відносяться до 1788-1791 років (див., напр.: [10, c. $626-632])$.

I. Кант, як відомо, іменуе свое учення трансцендентальним ідеалі- 
змом. Згідно $з$ цим ученням «всі предмети можливого для нас досвіду суть не що інше, як явища, тобто тільки уявлення, які в тому вигляді, як вони представляються нами, а саме як протяжні сутності або ряди змін, не мають існування самі по собі, поза нашою думкою» [8, с. 289]. Ключовим положенням в цьому визначенні $\varepsilon$ теза про те, що всі предмети можливого для нас досвіду слід розглядати як явища. Проте саме це ключове положення багатьма дослідниками інтерпретуеться як прямий доказ того, що позиція Канта агностична й ідеалістична. Ще за життя Канта в 1786 році була опублікована праця Ф.Г. Якобі «Про трансцендентальний ідеалізм», в якій автор доводить, що допущення предметів об'єктивної реальності, які впливають на відчуття пізнаючого суб'єкта, суперечить «духу Кантової філософії». Тому послідовник трансцендентальної філософії повинен відмовитися від подібного допущення, «ніби поза нами в трансцендентальному сенсі існують якісь речі» (див: [23]). Цим же шляхом - шляхом усунення «речі в собі» - пішли Фіхте і Шеллінг. Останній з мислителів називає положення, згідно з яким «поза нами існують речі», «основним упередженням, до якого зводяться всі інші», тому трансцендентальна філософія «необхідно повинна починатися із загального сумніву в реальності об'єктивного». Дане положення може бути достовірним для трансцендентального філософа тільки «через свою тотожність 3 положенням я існую» $[20$, с. $235-236]$.

Ми схильні погодитися з К.Р. Поппером у тому, що «Кант обрав для позначення своєї позиції двозначну і невдалу назву» [18, с. 302]. Це, до речі, розумів і сам Кант. У «Додатку» до «Пролегомен» він опонуе своєму рецензентові, який, на його переконання, «взагалі не розуміє, про що, власне, йдеться в цьому дослідженні», тоб́то в першій «Критиці». Кант «бажав би задля уникнення всякого помилкового тлумачення назвати інакше це... поняття [трансцендентальний ідеалізм]». Він намагається замінити його поняттям «критичний» або «формальний ідеалізм», указуючи на те, що він е ідеалізмом особливого роду, ідеалізмом форми, відмінним як від догматичного ідеалізму Берклі, так і від скептичного ідеалізму Картезія [9, с.601, 603-604]. Більш того, Кант говорить, що іделлізм проходить через весь його «твір, хоча далеко не складае душу системи» [9, с.602]. Тому він дорікає своєму рецензентові в далекому від істини тлумаченні суті його нових ідей, яку цілком можна за бажання угледіти із загального контексту твору. Нагадаємо, що рецензія, з якою в корені не згоден І. Кант, належала Християну Гарве. Вона була опублікована в «Додатку до геттінгенських вчених записок» 19 січня 1782 року із значними скороченнями 
і доопрацюваннями Іоганна Федера.

Загальний задум Канта в цілому зрозумілий вже 3 його відомого листа Марку Герцу від 21 лютого 1772 року, де він пише тільки про план твору під умовною назвою «Межі чуттевості і розуму» (йдеться про майбутню першу «Критику», видання якої відноситься до 1781 року). Показовим в контексті даної проблеми $є$ наступний вислів: «Те, що зміни суть щось дійсне, я не заперечую, як не заперечую, що тіла суть щось дійсне, хоча під цим розумію лише те, що щось дійсне відповідае явищу» [10, с. 531-532]. Кант, акцентуючи увагу на принциповій для розуміння його задуму відмінності між «трансцендентальним» $\mathrm{i}$ «трансцендентним», в «Додатку» до «Пролегомен» дае достатньо чітке визначення цих понять. «Слово трансцендентальне... означае не те, що виходить за межі всякого досвіду, а те, що по досвіду (a priori) хоч і передуе, але призначене лише для того, щоб зробити можливим досвідне пізнання. Коли џі поняття виходять за межі досвіду, тоді ïx застосування називається трансцендентним і відрізняється від іманентного застосування, тобто такого, що обмежується досвідом» $[9$, c. 602]. До речі на те, що «терміни трансцендентальний і трансцендентний не тотожні», Кант указував і в «Критиці чистого розуму» (див: $[8$, c. 213]). Тому Кант розглядае своє поняття «трансцендентальний ідеалізм» як таке, що позначае «пряму протилежність справжньому ідеалізму», тобто «матеріальному ідеалізму», котрий мав місце в історії філософії «від елеатської школи до єпископа Берклі». Мету ж свого «ідеалізму» він вбачае в тому, щоб «зрозуміти можливість нашого апріорного пізнання предметів досвіду». Всі попередні ідеалісти апелювали до інтелектуального споглядання, «оскільки їм в голову не приходило, що можна за допомогою відчуттів споглядати також а priori» [9, c. 603].

В.Віндельбанд вважае, що розділ під назвою «Спростування ідеалізму», включений Кантом до другого видання «Критики», «цілком відповідає всьому його ученню». Відтак центральна теза даного невеликого за обсягом нового розділу, суть якої полягае в тому, що «індивідуальна самосвідомість зовсім не лежить в основі уявлення про зовнішній світ..., а навпаки, сама стає можливою тільки на грунті розвинутого уявлення про зовнішні предмети», зовсім не випадкова i не така, що не відповіднає загальному задуму Канта [3, с. 90].

Формальний ідеалізм Канта, отже, не $\epsilon$ різновидом німецького діалектичного ідеалізму. Від суб'єкта, від його пізнавальних здібностей, залежить тільки форма людського пізнання, але зовсім не його зміст. Зміст же наших знань або безпосередньо, або потенційно співвідно- 
ситься 3 досвідом, що передбачае визнання онтологічної самостійності предметів об'єктивного світу. У зв'язку з цим Кант писав: «Якщо ми до сприйняття називаємо яке-небудь явище дійсною річчю, то це або означає, що ми в просуванні досвіду повинні натрапити на таке сприйняття, або не має жодного сенсу» $[8$, с. 290]. Спроба примирити емпіризм і раціоналізм, між представниками якого в Новий час велася гостра полеміка, привела Канта до ідеї трансцендентального пізнання, відмінного як від емпіричного, так і від чистого, спекулятивного, тобто раціоналістичного у вузькому сенсі цього слова, і в той же час має елементи схожості з ними обома. Трансцендентальне пізнання для Канта є «всяким пізнанням, що займається не стільки предметами, скільки видами нашого пізнання предметів, оскільки це пізнання повинне бути можливим a priori» $[8$, c. 60$]$.

Важливо також відзначити, що сам I. Кант мав можливість оцінити напрям розвитку його філософії в особі безпосереднього засновника класичного німецького ідеалізму - І.Г. Фіхте. Проживши достатньо довге життя, він останніми роками не викладав в університеті і внаслідок незадовільного стану здоров'я жив практично на самоті. Проте Кант листувався, зокрема з Фіхте, і таким чином залишався в курсі тих подій, які мали місце в інтелектуальному середовищі тогочасної Німеччини. Знайомство Канта з Фіхте, як відомо, відбулося в 1791 році (через десять років після виходу першої «Критики») і саме Канту він зобов'язаний, згідно з А. Гулигою, «,путівкою в життя“ великої філософії» (див: [6, с. 222-224]). У тому ж році анонімно вийшла робота Фіхте «Досвід критики будь-якого одкровення», яка привернула увагу широкої громадськості, що давно очікувала від Канта трактату з філософії релігії. Канту довелося спеціально виступити у пресі із заявою, що спростовувала його причетність до даної філософської праці. 3 тих пір Фіхте розглядали як безпосереднього послідовника критичної філософії І. Канта. На це вказуе і сам Фіхте, який в одному зі своїх листів Канту в 1798 році пише, що його філософська система «майже кожним з численної армії німецьких філософів вважаеться поданою 3 ваших рук» [17].

Проте, 7 серпня 1799 року Кант публічно заявляе про те, що вважае «науковчення Фіхте абсолютно неспроможною системою» $\mathrm{i}$ тому «відмежовується від будь-якої участі в цій філософії» [10, с. 625]. У цій «Заяві» він недвозначно указуе на причину «неспроможності» даного учення: «чисте науковчення $\boldsymbol{e}$ тільки логікою, яка зі своїми принципами не досягае матеріального моменту пізнання і як чиста логіка відволікається від його змісту» [10, с. 625]. Це свідчить про те, що для 
Канта неприйнятними $\boldsymbol{e}$ ті характерні риси філософії Фіхте, які, по суті, складають ядро філософії німецького ідеалізму. Йдеться, перш за все, про «безплідні хитрування» і про «тонкі спекуляції». Показово, що Кант ще в кінці 1797 року відзначав, що в нових роботах Фіхте достатньо повно виявився його «прекрасний талант живого, популярного викладу», і висловлював побажання більше не повертатися до «схоластики» $[10$, с.610]. На це Фіхте відповів, що думає «зовсім не про те, щоб розлучитися зі схоластикою», що «вивчае їі з бажанням і легкістю». «При тому, - писав він в листі від 1 січня 1798 року, - я володію значною її областю, якої донині торкалися лише мимоходом, тим більше не 3 наміром розвинути» (див: [17]).

Отже, з моменту знайомства двох німецьких філософів і до кантівської «Заяви» пройшло всього вісім років. Саме стільки часу знадобилося Канту, щоб усвідомити принципову відмінність між своїм критичним ідеалізмом і науковченням Фіхте. За цей час Фіхте без захисту дисертації і складання іспиту (до того ж і не маючи спеціальної освіти) отримує посаду професора і вчений ступінь магістра, читає лекції в Йенському університеті, видає «Філософський журнал», концептуально оформлюе свое філософське вчення і перетворюється на достатньо відомого і впливового філософа. Ним захоплюються багато мислителів того часу. Так, наприклад, Ф. Шлегель стверджував, що «він [Фіхте]. . . вперше відкрив і висунув правильний метод у філософії і зробив самостійне вільне мислення мистецтвом, - однієї цієї заслуги було б вже достатньо, щоб забезпечити його безсмертя. 3 тих пір, як ця чудова людина так могутньо збудила геній свободи і потрясла свідомість в їі внутрішній творчій глибині, з'явилися найважливіші зміни і револющіі і у всіх інших сферах людського мислення і творчості» (цит. за: [12, c. 211]).

Не дивлячись на достатньо невеликий проміжок часу, що відокремлюе публікації «Критики чистого розуму» Канта від цілого циклу робіт Фіхте, де висловлюються базові принципи його науковчення, можна все ж таки погодитися з К. Фішером, який останне десятиліття XVIII століття іменує «епохою», що підготувала «народження» Фіхте. Характеризуючи шлях від Канта до Фіхте, він писав: «Його початковий пункт Кант, його керівний принцип - дух Критики розуму, його попередник Рейнгольд, Енезідем - його скептичний супротивник, Маймон - його скептичний прихильник. Рейнгольд указуе на завдання, Енезідем і Маймон указують шлях, перший негативно, другий позитивно. В Енезідема можна навчитися, якого напряму критична філософія не повинна триматися, у Маймона - який напрям вона по- 
винна прийняти» (цит. за: [12, с. 193-194]).

Крім того, слід зазначити, що саме в цей період 3 подачі Канта відбувається становлення історії філософії як самостійної філософської дисципліни, що також об'єктивно сприяло закріпленню традиції розгляду кантівського «критичного ідеалізму» як початкового пункту класичного німецького ідеалізму. Одним із перших подібну думку висловив засновник кантівської школи Карл Леон Рейнгольд, який, як відомо, починав свій творчий шлях з популяризації учення Канта, згодом перейшов на фіхтеанські позиції і навіть спробував синтезувати «науковчення» Фіхте і «філософію віри» Якобі. Він, як і багато інших послідовників критичної філософії Канта, розцінював ї̈, перш за все, як пропедевтику, пролегомени, що вимагає систематичного оформлення і зведення до єдиного принципу.

Подібну думку висловив і Шеллінг в некролозі «Іммануїл Кант» (1804): «Він втілюе собою межу між двома епохами філософії-одну він назавжди завершив, іншу, мудро обмежуючись своєю тільки критичног метою, підготував в її негативному аспекті» [19, с. 32]. Проте сам Кант ще за життя категорично не погоджувався 3 такою оцінкою своєї фундаментальної праці. У вже згадуваній «Заяві 3 приводу науковчення Фіхте» він говорить про те, що намір «створити лише пропедевтику трансцендентальної філософії» «ніколи не приходив... [йому] у голову» і що вже в «Критиці чистого розуму» він «оголосив завершену цілісність чистої філософії крашою ознакою її істинності». А що стосується необхідності «оволодіння належною (беківською або фіхтевською) точкою зору», оскільки «кантівська буква, подібно до арістотелівської, нібито убиває дух», Кант «ще раз заявляе, що „Критику" в усякому разі слід розуміти буквально і розглядати тільки 3 позицій здорового глузду, достатньо розвиненого для абстрактного мислення» $[10$, с. $625-626]$.

Тому, на наш погляд, $\epsilon$ достатні підстави стверджувати, що I. Кант не $є$ засновником тієї філософської школи, яка увійшла до історії філософії під назвою німецького ідеалізму, а твердження, ніби останній $€$ результатом іманентного розвитку кантівського трансценденталізму, не зовсім відповідає дійсному стану справ. Кант наполягав на реальному існуванні речі самої по собі, його ж безпосередні послідовники пішли шляхом її проблематизації, асиміляції i, нарешті, елімінації. Поворотним пунктом у даному відношенні можна вважати роботу Якобі під назвою «Давид Юм про віру, Або ідеалізм і реалізм» (1787), що вийшла в один час 3 другим виданням першої «Критики», у якій указувалося на необхідності подолання кантівської речі самої по собі. Як 
відзначае Р. Кронер, «Якобі першим відкрив слабкий пункт критичної філософії, пункт, із якого починає свій розвиток і німецький ідеалізм» (цит. за: $[12$, с. 179]). Але ж Кант і в подальших своїх роботах свідомо акцентував увагу на тому, що він не бачить суперечності у визнанні існування цієї речі самої по собі і його трансцендентальним ідеалізмом. Більше того, він був переконаний, що «система критики покоїться на міцній основі» $\mathrm{i}$ що «вона буде потрібна людству і в майбутньому для високих помислів» $[10$, с. 626$]$.

3 вищесказаного можна зробити висновок про те, що філософія Канта, дійсно, стала поштовхом до подальшого розвитку німецької філософії, проте побоювання Канта «бути не зрозумілим» виправдалося. Просто вражае той факт, що на кінець його життя було опубліковано близько двох тисяч робіт, присвячених різним аспектам кантівської критичної філософії і що належали перу близько семи сотень авторів. «Критика чистого розуму привертала або відштовхувала; але,як справедливо відмічає Е. Кассірер, - ніде не було навіть щонайменшого розуміння того, що вся кантівська постановка питання абсолютно не входить в рамки, встановлені традиційними межами філософських шкіл. Тривалий час інтерпретація кантівської системи зводилася до того, чи слідуе її мислити і визначати як, ,ідеалізм“" або як „реалізм“, як „емпіризм“ або як „раціоналізм“» [11, с. 199]. У іншому місці своєї роботи «Життя і вчення Канта» він відзначае, що «ще за життя Канта різні тлумачення його учення різко протистоять один одному. Старше покоління бачить в ньому знищення і руйнування метафізики: Мендельсон виражае загальнопоширений настрій, скаржачись на „всеруйнівника“ Канта. Але $\boldsymbol{\epsilon}$ вже й інші, представники молодого покоління, які бачать в „Критиці чистого розуму“ не що інше, як підготовку і ,пропедевтику“, яку з ентузіазмом вітають в ній зорю майбутньої метафізики» [11, с. $377-378]$.

Проте ні представники раціоналістичної шкільної філософії a la Wolf, ні представники «популярної філософії», ні ті, які називали себе послідовниками Канта, не змогли гідно оцінити його «коперніканський переворот». Ніхто з них не побачив у його філософії методологічну складову, яка, з одного боку, виводить кантівський трансцендентальний ідеалізм за рамки традиційної онтології, якою, по суті, була колишня метафізика, а з іншого, - долае спекулятивізм («догматизм» в термінології самого І. Канта) як одну з характерних рис філософських систем подальших німецьких ідеалістів.

Підсумовуючи наше невелике дослідження, хотілося б вказати на деякі причини неадекватного розуміння трансцендентальної філософії 
Канта його сучасниками і найближчими послідовниками, які заклали, відповідно, традицію спотвореної її інтерпретації в історії філософії:

1. Важкий стиль написання «Критики чистого розуму», наявність великої кількості філософських понять, яким Кант давав авторське тлумачення, відмінне від загальноприйнятого, i, до того ж, визначення одного і того ж поняття могло бути різним у різних місцях роботи.

2. Головні ідеї трансцендентального ідеалізму стали предметом активного обговорення не після виходу робіт самого Канта, а після численних спроб його інтерпретації і популяризації, здійснених засновниками його «школи». Тому можна припустити, що «знали» це учення не за оригіналом. Як говорив Шеллінг, він «проклав коротший шлях» до експлікації «критицизму».

3. Принципова новизна ідей, що розробляються і обгрунтовуються Кантом, які він самостійно обмірковував більше десяти років, перш ніж винести на публічне обговорення. Основні ідеї його учення виходять за рамки будь-якого відомого на той час філософського напряму, більше того, Кант свідомо поривав зі всією попередньою філософською традицією. Звичайно ж, усвідомлення цієї новизни вимагало певного часу i, крім того, необхідного наукового і філософського рівня тих людей, хто її вивчав.

4. Однозначне переважання ідеалістичної філософії в Німеччині, як до Канта (Лейбніц, Вольф), так і після нього (Якобі, Фіхте, Шеллінг, Гегель). I, крім того, пов'язана з цим загальна налаштованість на побудову філософської системи, виходячи з єдиного основоположного принципу. Слід також відзначити, що послідовне проведення діалектичного методу стало можливим саме завдяки такому моністичному підходу.

5. Специфічне розуміння співвідношення філософії і науки, перш за все природознавства. Якщо Кант, ставлячи питання «Як можлива метафізика в сенсі науки?», шукав відповідь в аналізі математики і природознавства, що успішно проявили себе на той час, то «німецькі ідеалісти» повертаються до поняття натурфілософіï. Для них відповідно до діалектичного методу наукове знання ототожнюеться 3 постійним розширенням, «синтезом», «зняттям», що не вимагає обмежувати розум в його пізнанні. Отже, філософія і є найвищою наукою. 
Головний висновок, який можна зробити на основі проведеного дослідження, полягає у тому, що теоретичну філософію І. Канта не можна розглядати лише у зв'язку зі школою німецького ідеалізму, відшукуючи тільки ті ідеї, які знайшли подальший розвиток у Фіхте, Шеллінга і Гегеля. Більш того, його взагалі не можна зараховувати до якого-небудь одного філософського напряму. І. Кант - поворотна фігура в історії світової філософії, яка, так або інакше, вплинула на її подальший розвиток. Його ідеї були поштовхом до розвитку як раціоналістичного, так і ірраціоналістичного напрямів. Досить пригадати засновника сучасного ірраціоналізму А.Шопенгауера, який, використовуючи кантівську термінологію, говорить про «річ саму по собі» $\mathrm{i}$ «світ як уявлення». Схожа ситуація з Е. Гуссерлем і його феноменологією. Не говорячи вже про різні школи неокантіанства і «критичний раціоналізм» K.Р. Поппера. Тому філософія суб'єкта, що заперечила існування «речей самих по собі», і діалектика як теорія розширення наукового знання і як теорія розвитку є надбанням не самого Канта, а однієї із філософських шкіл, які склалися на основі творчої переробки деяких його ідей, - школи класичного німецького ідеалізму.

\section{1 Бібліографія}

[1] Асмус В.Ф. Иммануил Кант. - М.: Наука, 1973.

[2] Бакрадзе К.С. Проблема диалектики в немецком идеализме // Бакрадзе К.С. Избранные философские труды, т. І. - Тбилиси: Издво Тбилисского университета, 1981. - С. 27-241.

[3] Виндельбанд В. История новой философии в её связи с общей культурой и отдельными науками: В 2 т. Т. 2: От Канта до Ницше. - М.: Гиперборея, Кучково поле, 2007.

[4] Гегель. Энциклопедия философских наук. Т. 1. Наука логики. М.: Мысль, 1974.

[5] Гулыга А.В. Немецкая классическая философия.-М.: Рольф, 2001.

[6] Гулыга А.В. Кант. - М.: Мол. гвардия, 1981.

[7] Д.лугач Т.Б. И. Кант: от ранних произведений к «Критике чистого разума».- М.: Наука, 1990. 
[8] Кант Н. Критика чистого разума.-М.: Өксмо; СПб.: Мидгард, 2007.

[9] Кант И. Пролегомены ко всякой будущей метафизике, могущей появиться как наука // Кант И. Критика чистого разума.- М.: Эксмо; СПб.: Мндгард, 2007.-С.507-610.

[10] Кант И. Трактаты и письма. - М.: Наука, 1980.

[11] Кассирер Ө. Жизнь и учение Канта.-СПб.: Университетская книга, 1997.

[12] Куиаков Ю.В. Нариси з історії німецької філософії Нового часу: Навчальний посібник. - К.: Центр навчальної літератури, 2006.

[13] Ленин В.И. Материализм и эмпириокритицизм // ПСС.-М.: Изд-во полит. лит-ры, 1980.- Т. 18.

[14] Mотрошилова H.B. Рождение и развитие философских идей: Историко-философские очерки и портреты.-М.: Политиздат, 1991.

[15] Нарский Н.С. Кант. - М.: Мысль, 1976.

[16] Ойзерман Т.И. Учение И. Канта об априорном познании // Кантовский сборник. Межвузовский тематический сборник научных трудов. Вып. 22. - Калининград: Изд-во КГУ, 2000. - С. 4-30.

[17] Писвмо Фихте-Канту от 1 января 1798 года http://vispir.narod.ru/fichte/fihte2.htm

[18] Поnnер K.P. Предположения и опровержения: Рост научного знания. - М.: АСТ, 2008.

[19] Пелиине Ф.В.Й. Иммануил Кант // Шеллинг Ф.В.Й. Сочинения в 2 т.: Т. 2. - М.: Мысль, 1989. - С.27-33.

[20] IIелиине Ф.В.Й. Система трансцендентального идеализма // Шеллинг Ф.В.Й. Сочинения в 2 т.: Т. 1. - М.: Мысль, 1987.C. 227-489.

[21] Шеллине Ф.В.Й. Философские письма о догматизме и критицизме // Шеллинг Ф.В.Й. Сочинения в 2 т.: Т. 1. - М.: Мысль, 1987.C. $39-88$. 
[22] ЛГинкарук В.И. Теория познания, логика и диалектика И. Канта (И. Кант как родоначальник немецкой классической философии).- К.: Наукова думка, 1974.

[23] Якоби Ф.Г. О трансцендентальном идеализме // Новые идеи в философии, сб. 12. СПб., 1914. / http://vispir.narod.ru/jacobi.htm

[24] German Idealism // The Internet Encyclopedia of Philosophy http://www.iep.utm.edu/germidea/

Надійила до редакцій 18 травня 2010 р. 